\title{
Originalartikel
}

\section{Den øjeblikkelige religiøsitet}

\section{Nadja Ausker}

Region Hovedstaden, Rigshospitalet

nadjaausker@gmail.com

Ausker, N. (2014). Den øjeblikkelige religiøsitet. Tidsskrift for Forskning i Sygdom og Samfund, nr. 20, 93-112.

I denne artikel argumenterer forfatteren for en ny tidsforståelse i forskningen af religiøsitet under sygdom. Hun påpeger, hoorledes forestillingen om en kontinuert tid har præget forskningen i religiøs coping indtil nu, og at disse tidsopfattelser ikke er dækkende i forhold til at kunne beskrive religiøs forandring under sygdom. Som en del af en modernitetstendens gav kræftpatienterne i undersøgelsen udtryk for, hoorledes at religiøsiteten blev anset for at være et forbrugervalg, hoor nogle varer var særligt attraktive, da de kunne forbruges øjeblikkeligt og ikke var forbundet med noget negativt. Forbrugerholdningen til religiøsiteten bidrog endvidere med en særlig tidslig mulighed, hoor religiøsiteten kan tilvælges efter behov i øjeblikket - en form for religiøsitet som forfatteren kalder Pro necessitate religiøsitet. Samtidigt var det af betydning for informanterne, at de kunne bevare en stor del kontinuitet med deres tidligere værdier og religiøsitet. Forbrugerreligiøsiteten muliggør netop, at brud og kontinuitet kan være simultane.

\section{Religious change in an instant}

In this article the author argues for a new "pointillist" understanding of time when studying change of religiosity and life crisis, a concept she gets from Baumans description of the consumer society, where consumers moves between points of time. The author argues that the consumerist society's understanding of time influence the way that cancer patients in a Danish hospital reflects on their religiosity and continuity with previous values. Therefore the patients in this ph.d.-study stress both their religiosity as it was before their life threate- 
ning disease and the possibility of changing values for a point in time if needed. The author hereby challenge the understanding of time that have influenced the research in religion and health which is strictly continual, as the theories of religious coping states a direct coherence between past and present religiosity mediated by the crisis. The author therefore introduces a concept of "religiosity Pro necessitate" whereby "pointillist" religiosity and continuity with previous values are simultaneous possibilities.

\section{Introduktion}

Denne artikel vil, med udgangspunkt i interviews med 21 yngre kræftpatienter, beskrive hvorledes religiøsitet forstås som et objekt, der i øjeblikket er til forhandling. Denne opfattelse af religiøsitet, som disse kræftpatienter giver udtryk for, er i modsætning til den måde, religiøsitet traditionelt bliver opfattet inden for sundhedsforskningen. Hvor sundhedsforskningen generelt beskæftiger sig med religiøsitet, som enten kan have en effekt på sygdomshåndtering og coping (se eks.: Johannessen-Henry et al., 2010; K. I. Pargament et al., 2005; Kenneth I. Pargament \& Raiya, 2007; Thune-Boyle et al., 2012) eller forhold mellem religiøsitet og fysisk og mentalt helbred (se eks.: H. G. Koenig, 2009; Harold G. Koenig et al., 2012), vil denne artikel diskutere religiøsitet ud fra et religionssociologisk forandringsperspektiv.

Den religionssociologiske forskning i religiøsitet og sygdom har ofte haft fokus på konversionen og den religiøse forandring, der kan opstå som følge af en livsforandrende begivenhed (se eks.: Andersen et al., 2011; Rambo, 1993; Robbins, 1988). Samtidigt er der i denne litteratur ofte et fokus på bruddet, ligesom kvantitative undersøgelser af livsbegivenheder og religiøsitet, også bærer præg af at ville forstå den religiøse konversion (Smith, 2006).

Med afsæt i teorier om forbrugerisme vil informanternes religiøsitet blive analyseret som en måde at forholde sig til religiøsitet på, hvor religiøsitet er en øjeblikkets mulighed, og hvor religiøsitet kan til- eller fravælges efter behov. Artiklen er baseret på interviews med leukæmi og lymfekræft patienter, alle mellem 18 og 40 år. Dataindsamlingen blev foretaget på Rigshospitalet i 2009-2011¹. Artiklens pointer er baseret på en del af en større analyse af religiøs forandring i forbindelse med en livstruende sygdom (Ausker 2012).

I forskningen i religiøsitet i moderniteten og i religiøsitet og sygdom kan man identificere to forskellige måder at anskue tid og værdier på. Disse måder, mener jeg, har primært sin grund i de religionsopfattelser, der ligger bag ved teorierne, 
og til at begynde med vil jeg i denne artikel beskrive to forskellige former for anskuelser, nemlig den øjeblikkelige og den kontinuerte tid, for at sætte rammen for den videre analyse.

Den slovensk-tyske sociolog Thomas Luckmann beskriver i sin bog Invisible religion (1967), hvorledes religion i moderniteten er blevet til et privat valg blandt andet som følge af modernitetens og sekulariseringens udgrænsning af det religiøse til privatsfæren. Som følge heraf blev individets følelse af autonomi forbundet til en forbrugerorientering, mener Luckmann (Luckmann 1967, p. 98). Dette skyldtes mest af alt mangler på fælles samfundsgivne normer, og at alt herefter var lagt ud til individets til- og fravalg. Individets valgmuligheder gjaldt således både venner, naboer, hobbyer og generel mening med livet (Luckmann, 1967, p. 98 ff).

Uden at gå så vidt, at alt er fuldstændig valgfrit, beskæftiger en del af den moderne teori om forbrugersamfund sig med, hvad forbrugermentaliteten implicerer for menneskelig handlen generelt og i forholdet til valg af religiøsitet specifikt. At omtale valget af religiøsitet som at vælge fra et smørrebrødsbord eller handle i et spirituelt supermarked er udtryk, der forsøger at beskrive denne forbrugsliggørelse af religiøsiteten (Roof 1999; Wuthnow 2005, pp. 106-126, 281-286). At religiøsiteten i moderniteten er som et supermarked eller et smørrebrødsbord dækker over en række antagelser om de valgmuligheder angående religiøsitet, som individer har mulighed for i moderniteten. Antagelserne er: 1) at individet vælger eksempelvis trosforestillinger og religiøs praksis 2) ud fra mange mulighederne, og 3) at individets bevæggrunde for at foretage dette valg er lyst og behov. Disse måder at forholde sig til religiøsitet på i forbrugersamfundet, er blandt andet grundet en særlig opfattelse af tid, som jeg vil beskrive i det følgende.

Den øjeblikkelige lyst som styrende for den menneskelige handlen har den polske sociolog Zygmunt Bauman særligt beskæftiget sig med i bogen Consuming Life fra 2007 (Bauman 2007). Bauman mener, at mennesket til alle tider har forbrugt, men med forbrugerismen gik det almindelige forbrug fra at være "regimeneutralt" til at være det styrende princip for både gruppe- og individueladfærd (Bauman, 2007, pp. 23-28). I det moderne forbrugersamfund er det ikke forbruget for at opnå komfort, agtelse og respekt, der er det vigtige. Det er snarere den øjeblikkelige behovsopfyldelse, hvor den tidslige faktor i forbrug hurtigt og smid hurtigt væk kulturen er essentiel. "Liquid modern consumerism is notable, more significantly than for anything else, for the (thus far unique) renegotiation of the meaning of time" (Bauman, 2007, p. 32). Fra tidligere at have handlet ud fra en lineær eller cirkulær tidsforestilling organiseres vores (forbruger)adfærd nu i forbrugerkulturen i en punktlig tid, hvor alt enten sker i øjeblikket og hvis ikke, så 
vil øjeblikket forpasse. Dette kan man kalde den øjeblikkelige tid. Vi skal gribe muligheden hurtigt, ellers går den tabt, og vi må så bevæge os hurtigt videre til næste punktlige øjeblik med nye muligheder.

Bauman påpeger endvidere, at individer i et samfund, der er præget af at få, smide-væk og erstatte i en stadig strøm, også vil skulle selvfremstille sig som en attraktiv vare, forøge sin værdi og sælge sig selv (Bauman, 2007, pp. 32-36). At forøge forbruget og væksten bliver i forbrugersamfundet målet, og hermed er overflodssamfundet skabt. Vi køber og forbruger ting i en stadig hurtigere strøm, ikke alene på grund af egentlige behov, men fordi tingene er tilgængelige, og forbruget er muligt. Dette skaber en tendens til overflod, som forplanter sig til alle dele af samfundet, siger Bauman. Forbrugerne bliver bombarderet med dekontekstualiserede kommunikationer og marketingstiltag i høj hastighed, og derved bliver det sværere at skabe en orden og en samlende fortælling. I stedet bliver omgivelserne, arbejdslivet og livsstilen fragmentarisk og hurtigt udskiftet i søgen efter lykken, som forventes at være en følge af forbruget (Bauman, 2007, pp. 41-46).

Forbrugersamfundet drives af, at medlemmerne aldrig er helt stillet tilfredse, og derfor er produkternes signalværdi stadigt hastigt skiftende, samtidigt med at nye behov skabes og gamle dækkes. Bauman fortsætter: "Each single promise must be deceitful, or at least exaggerated.....without the repetitive frustration of desire, consumer demands would quickly run dry" (Bauman, 2007, p. 47). Bedrag er dermed også en del af forbrugersamfundets nødvendige hjul. Det er et samfund, hvor vejen mellem butik og skraldespand er meget kort og med tilbud om, at man hele tiden kan starte forfra i skabelsen af ens identitet gennem markedets "identity kits". Og forestillinger, der før var fælles, er i det moderne samfund privatiseret og individualiseret, mener Bauman (Bauman, 2007, pp. 48-49).

Dermed tegner Bauman, i tråd med hans generelle tanker om moderniteten som flydende, billedet af et individ, hvis identitet er omskifteligt øjeblikkeligt, og hvis liv i forbrugerræset præges af at dække det næste kunstigt skabte behov. Det er ikke umiddelbart opløftende læsning, men Bauman får præciseret nogle tendenser i moderniteten, som rækker udover meningsdannelsen og religiøsiteten, som forbrugerkulturen kan have indflydelse på. Både tendenser om at forholde sig til religiøse forestillinger som produkter, der kan undersøges, vælges og sælges fragmentarisk, samt ved oplevelsen af den øjeblikkelige tid, der følger disse tendenser.

I religionsforskning tales der særligt ofte om forbrugsliggørelse af religiøsiteten i forbindelse med spiritualitet og i beskrivelsen af vigtigheden af den personlige individualitet og autonomi for valget af religiøsitet (Ahlin, 2005; Ausker, 2004; 
Heelas, 1996, 2008). Men disse studier sammenkobles sjældent med forskningen i religiøse forandringer, hvor der ofte er fokus på sammenhængen mellem en begivenhed og en anden efterfølgende religiøsitet $\mathrm{i}$ form af en religiøs forandring i det, der traditionelt betegnes som konversionsforskning (Andersen et al., 2011; Warburg, 2008).

Baumans opfattelse af værdier som fuldstændige ombyttelige står ligeledes i modsætning til store dele af forskning i religiøs coping, hvor tid også forstås kontinuert, da det i denne forskning anses for at være sandsynligt, at en livsbegivenhed eller krise kan medføre en fuldstændig ændret religiøsitet. Altså at individet har en religiøsitet, kommer ud for en alvorlig hændelse (bliver skilt, bliver syg, oplever en naturkatastrofe eller lignende), og denne begivenhed bliver for individet point of no return i forhold til at blive et andet og nyt menneske med ændrede værdier og religiøsitet.

\section{Religiøs coping og religiøs forandring}

Forskningen i coping har beskæftiget sig med, hvorledes individer forsøger at genetablere psykisk ligevægt eventuelt gennem ændrede adfærd eller værdier:

"(...) efforts to master conditions of harm, threat, or challenge when a routine or automatic response is not readily available. Here environmental demands must be met with new behavorial solutions or old ones must be adapted to meet current stress (Monat \& Lazarus, 1985, s. 5)

At cope religiøst er at benytte ens religiøsitet aktivt til at håndtere en krise, og et eksempel på denne forståelse er den amerikanske psykolog Kenneth Pargament. Pargament er forgangsmand inden for forskning i religiøs coping, som han definerer: "ways of understanding and dealing with negative life events that are related to the sacred" (Pargament and Raiya 2007, p. 743). Pargament argumenterer for, at det personen finder helligt (sacred) kan forandre sig i forbindelse med en krise, men forklarer samtidigt, at individet i første omgang vil forsøge at bevare og forsvare sine værdier (Pargament 1997, p. 111). En meningsbearbejdning kan altså medføre større eller mindre religiøse forandringer ifølge denne teori. Den første strategi, et menneske vil gribe til, når vi møder en stressfuld situation, er ifølge coping teorierne at forsøge at fastholde vores verdenssyn, værdier og fastholde den måde, vi forsøger at bevare vores værdier. Hvis vejen mod, hvad vi finder betydningsfuldt, ikke kan fastholdes, vil individet forsøge at finde nye veje mod 
det samme mål. Det kan eksempelvis være, hvis man går i parterapi for at bevare et ellers forlist ægteskab og her igennem må ændre sine værdier for at opnå sine mål - hvor målet er et lykkeligt ægteskab. Hvis man så kommer i en situation, hvor man ikke kan bevare de værdier, man havde før, det kan for eksempel være ved alvorlig sygdom, så kan man finde nye værdier. Individet revurderer situationen, og hvor en tidligere værdi kan have været at dyrke sport, kan en ny værdi blive at kunne leve uden smerter. Når alvorlig nok kan den stressudløsende faktor ændre både på ens grundlæggende værdier og vejene dertil. Individet vil derfor genskabe nye drømme og måder at nå dertil (Pargament, 1997, pp.112-13). Coping mekanismer har altså et formål: i første omgang at forsøge at holde fast, men hvis dette ikke kan lade sig gøre så at forandre værdibaserede mål eller midler til at opnå mening så hensigtsmæssigt som muligt.

Livsforløb - fortid

-

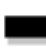

Figur 1 Tidsbegrebet $i$ coping og konversionsforskningen - Den kontinuerlige tid

Pargament, og andre med ham inden for copingforskning, opererer således med et meget liniært tidsbegreb, en kontinuerlig tid, hvor livsbegivenheder medfører, at mennesker tager deres værdier op til revision (figur 1). Værdierne er hermed knyttet sammen med tiden på den vis, at man var nogen før, og man efter begivenheden eventuelt er en anden med andre værdier, hvis begivenheden har været alvorlig nok. Forandring af ens religiøsitet kan være et sådant værdiskift² Et skift indenfor religiøs coping er eksempelvis, når de tidligere religiøse strukturer fejler som copingmekanisme, men religion som sådan ikke afvises som en passende strategi. I denne proces kan individet vælge at genfortolke begivenheden, personen eller det guddommelige, og den negative begivenhed kan redefineres positivt som en spirituel mulighed, individet kan søge religiøs renselse, eller begivenheden kan i sidste ende tolkes som Guds straf (Pargament, 1997, pp. 219-233). Pargament pointerer, at religiøs forandring er en integreret del af den almindelige religiøse oplevelse (Pargament, 1997, p. 213).

Pargaments tidsopfattelse, hvor tiden og værdier forstås som noget, der kontinuerligt hænger sammen med, hvem man var før krisen, kommer også til ud- 
tryk i sammenhængen mellem krisens alvorlighed og ændringen af værdier. I Pargaments optik vil konversioner eller fuldstændige omvendelser oftere ske, når krisen er så alvorlig, at den kræver ændring af både midler og mål i individets vej mod at skabe mening og formål i livet. Dette er i modsætning til de beskrevne mindre forandringer og skift, hvor individet fastholder meningen, men skifter vejen. Der er altså en direkte sammenhæng mellem tiden før krisen, krisens alvorlighed og bruddet med kontinuiteten - i form af skiftet. Begivenheden kan bryde kontinuiteten; ingen kriser, ingen brud, da værdiernes (og dermed religiøsitetens) adækvathed ikke bliver udfordret. At Pargament i sin teori sætter lighedstegn mellem krisens alvorlighed og graden eller omfanget af religiøs forandring, er en følge af copingteoriens religionsforståelse, hvor religion anses for en blivende og grundlæggende værdi, der sjældent forandres. Pargament beskriver da også, at religion under krisen kan betragtes som et reservoir på den vis, at "when people are stressed, the religious reservoir is often tapped and revealed for whatever it does (or does not) hold." (Pargament, 1997, p. 5). ${ }^{3}$

\section{Metode}

Mine interviews med de 21 informanter blev på sin vis tilrettelagt ud fra en forestilling om kausale sammenhæng mellem begivenheder og religiøsitet før og efter sygdommen. Jeg ønskede at forsøge at beskrive, hvordan kræftpatienters religiøsitet forandrede sig eller forblev de samme, i forbindelse med en alvorlig kræftsygdom. Undersøgelsen er derfor en longitudinal undersøgelse af værdiændringer i forbindelse med en alvorlig diagnose, for at understøtte en konklusion om forandring eller ingen forandring - over tid (De Vaus, 2005; Repstad, 2007). Ved at inddrage tidsperspektivet i min undersøgelse, ville jeg få mulighed for at kvalificere udtalelser om sammenhænge mellem ændring af religiøsitet og sygdom. Således lagde undersøgelsen sig på linje med mange tidligere undersøgelser af livsbegivenheder og religiøsitet, hvor konversion og religiøs forandring forventes at hænge sammen med en livsbegivenhed (Rambo, 1993; Robbins, 1988)

Da jeg anskuede religiøsitet i forbindelse med sygdom ud fra et forandringsperspektiv, forventede jeg, at religiøsiteten kunne forandres helt eller delvist, og jeg tilrettelagde derfor undersøgelsen til at strække sig over en tidsperiode på et år til halvandet. Jeg interviewede 21 leukæmi og lymfekræft patienter, alle mellem 18 og 40 år. Informanterne blev interviewet af to omgange, første gang forholdsvis tæt på diagnosetidpunktet, 1-4 måneder efter diagnose og andet interview var 
et år til halvandet efter det første interview. Dataindsamlingen blev foretaget på Rigshospitalet i 2009-2011, og informanterne blev systematisk inkluderet i studiet ${ }^{4}$ . Jeg havde tilrettelagt undersøgelsen således, at informanterne skulle være yngre, da det kunne formodes at den eksistentielle rystelse ved at blive alvorligt syg, og de fleste informanter var et sted i deres liv, hvor identitet og livsvej i høj grad stadig var til forhandling.

Baggrunden for valget af de to nedslag $\mathrm{i}$ informanternes tid var, at tiden kort efter diagnosen har vist sig at være en periode med mange eksistentielle tanker hos danske patienter (la Cour, 2008), og samtidig skulle informanterne tydeligt kunne huske tiden før diagnosen. Endvidere ønskede jeg tidsmæssigt at give rum til en forandring. Den anden runde af interviews var dog ikke klare post-interventionsinterview, da informanterne i denne periode henholdsvis var behandlingsfri, havde fået tilbagefald, fået alvorlige senfølger af behandlingen eller var stadig $\mathrm{i}$ behandling grundet mangel på knoglemarvsdonor. Således var mange ikke ude af hospitalssystemet ved andet interview. En af informanterne døde i løbet af min dataindsamlingsperiode, en anden informant døde lige efter dataindsamlingen var færdiggjort. Undersøgelsen blev baseret på i alt 40 interviews, hvoraf de 21 i første runde var semi-strukturerede, dybdegående livshistoriefokuserede interviews, og de fleste foregik på hospitalet. Anden runde interviews bestod af telefoninterviews på under en times varighed.

Informanternes livshistorier skal ikke forstås som deres livsbegivenheder per se, men en måde hvorpå informanterne repræsenterer, præsenterer og fortolker deres tanker, følelser og oplevelser. Dette er vigtigt at holde fokus på i forbindelse med en analyse af en eventuel kausal sammenhæng mellem en begivenhed (sygdommen) og en virkning (religiøs forandring). Men livshistorier er samtidig en aktørorienteret måde at behandle og forstå religion og religiøsitet på, hvor fokus kun er på det ydre og institutionelle såsom dogmer og ritualer, når det har betydning for aktøren (Mikaelsson, 2006). Derfor er livshistorierne en hensigtsmæssig måde at undersøge religion, som det konstrueres, forstås, opleves og leves af informanterne, og en måde hvorpå man kan forholde sig til nyere religionssociolo-

gisk teori om hverdagsreligiøsitet, der netop betoner den individuelle oplevelse som analysens center (Ammerman 2007).

At jeg vendte tilbage til mine informanter efter det første interview gav mig mulighed for at veksle mellem teori-empiri, idet jeg hermed fik mulighed for at spørge ind til teoribaserede elementer, som første runde af dataindsamlingen foranledigede (Layder, 1998, p 42-51). Jeg tog derfor udgangspunkt i hvert enkelt tidligere interview ved geninterviewet og spurgte herudover generelt ind til fem cen- 
trale temaer. Dette er en analysemetode, hvor man veksler mellem teori og empiri, og lader de to områder være informeret af hinanden, og hermed forsøges skellet mellem induktive og deduktive arbejdsformer at overvindes. At anden runde af interviewene foregik telefonisk var af primært praktiske årsager. På trods af at telefoninterviews kan være problematisk $\mathrm{i}$ forhold til at få informanternes fortrolighed og opfange non-verbalt sprog (Repstad 2007, pp. 97-98), så viste det sig, at fortroligheden hurtigt blev genskabt i telefonsamtalerne, og at alle informanterne kunne huske vores første samtale trods det store tidsspænd. Mange informanter fortalte mig også ved andet interview dybt personlige ting, og jeg har derfor ikke nogen grund til at forvente, at en anden interviewform bevirkede, at mine resultater pegede på mindre religiøse forandringer og stor grad af kontinuitet.

I min undersøgelse af religiøs forandring i forbindelse med sygdom kunne jeg konkludere nogle brud eller ændringer af religiøsiteten, men jeg fandt samtidigt en høj grad af ønsket kontinuitet med tidligere værdier. Samtidigt fandt jeg måder at forholde sig til religiøsiteten og tiden på, som var mere øjeblikkelige end kontinuerte. I de følgende afsnit vil jeg beskrive, hvordan den øjeblikkelige tid kom til udtryk, og hvilke konsekvenser det må have for vores forståelse af tid og værdier i forbindelse med en krise. Men først vil jeg beskrive, hvordan informanterne beskrev sig selv som religiøse forbrugere, da denne selvopfattelse sætter rammen for den videre analyse.

\section{Forbrugerreligiøsitet}

I interviewene med kræftpatienterne på Rigshospitalet fandt jeg blandt informanterne en særlig måde at forholde sig til religiøsiteten på, som kan kaldes en forbrugerorientering. Da denne orientering, eller måde at forholde sig til religiøsiteten på, er medbeskrivende for informanternes generelle religiøsitet og opfattelse af forandring over tid, må analysen af informanternes tidsforståelse begynde her. Jeg vil derfor i det følgende beskrive det generelle i en sådan måde at forholde sig til religiøsiteten på og dernæst beskrive det med eksempler fra materialet.

I teorien om forbrugerkulturen er individualismen tæt forbundet hermed, da det er retten til det frie forbrugervalg, der lægges vægt på. Kun du alene kan mærke, hvad du vil have, er et af kulturens mantra (Campbell, 2004). Informanterne i studiet beskriver også noget, der virker som en forpligtigelse til at tage et forbrugervalg, som beskrevet her af Kristian ${ }^{5}$ : 
Nadja: Har du tænkt over det [døden] her efter, du er blevet syg, har det fyldt mere?

Kristian: Nej egentlig ikke, jeg har tænkt over, om jeg burde tænke mere over det, og jeg kan ikke komme videre.

Nadja: Fordi du synes, at du burde tage stilling til det eller hvad?

Kristian: Jahhh, det kan godt være, jeg burde tænke lidt mere over døden, og hvad der sker bagefter, men det har jeg egentlig ikke rigtig haft lyst til, det er ikke rigtig noget, jeg forbinder med noget behageligt, altså ligesom i nogle religioner, hvor det er godt at dø næsten, ikke altså, sådan ser jeg det egentlig ikke. Jeg ville egentlig gerne forske lidt i andre religioner, det er også meget sjovt, når man også rejser $\mathrm{i}$ Østen og ser, hvordan deres forhold er og sådan noget, men altså det er ikke noget, jeg lige har gjort. Så ja, det virker meget hyggeligt derude altså, nu rejste jeg rundt også med Filip, vi var i Laos i 3 uger, hvor de alle sammen er buddhister, det virker meget sådan harmonisk. (Interview med Kristian d. 18. januar 2009)

Kristian vil godt være den gode forbruger og har derfor tænkt over, om han "burde tænke mere over det", men han forbinder ikke døden med noget rart og finder det derfor svært at tænke på. At Kristian mener, at han burde tænke mere over det, påpeger et andet karakteristikum ved forbrugersamfundet, nemlig at vores identitet er forbundet med vores forbrugervalg og personlige smag (Campbell, 2004)(p.31)

Hvis ikke vi vælger os selv og fremhæver vores autentiske selv, så er vi ikke i forbruger kulturen (Bauman, 2007). At have valgt bliver derfor ofte fremhævet af kræftpatienterne, som Laura i nedenstående citat, hvor vi taler om, om hun ville tilvælge en religiøsitet på et tidspunkt:

Laura: Det er faktisk lidt interessant, hvad jeg så ville, men jeg tror stadig væk ikke helt, det ville være kristendommen, jeg ville vende mig til. Det kan godt være, jeg ville tage en samtale med en præst, når det nu var, men mere for den eksistentielle samtale og få det input. Jeg tror ikke, jeg ville kunne nå at tro på gud sådan rigtig i mit hjerte.

Nadja: Tror du, buddhismen og sådan noget ville det fylde mere, tror du, at det ville være noget, du så ville vende dig imod, nu er det jo helt hypotetisk, det er svært at forholde sig til? 
Laura: Måske altså tanker omkring, jeg ville nok bruge nogle af teknikkerne, altså mere end jeg ville gøre mig tanker om reinkarnation, det kan i bund og grund også være lige meget, altså det finder man ligesom ud af til den tid. Men teknikkerne i forhold til at få en god sidste tid og få ro i sjælen og få ro i sindet og sådan noget, det kunne jeg nok godt. (Interview med Laura d. 17. august 2009)

Laura påpeger forbrugeraspektet i det religiøse. Religiøsiteten skal kunne give hende noget, eksempelvis i form af teknikker eller input. Hermed understreger hun det religiøse supermarkeds karakter: Laura vælger de dele, hun ville kunne bruge i sin selvskabelse. Og selvom jeg stiller et hypotetisk spørgsmål, så ved Laura godt, hvilke dele hun ville vælge til, og hvilke hun ville vælge fra - og hun ved, at hun ville have mulighed for at sammensætte efter sin egen overbevisning.

At vælge og sammensætte vores religiøse identitet er med til at højne vores egen værdi som vare (Bauman, 2007, pp. 50-53). Processen er dermed dobbeltsidet; vi skaber os selv gennem forbrug, og derved fremstår vi som en bedre vare. Forbrugernes egen smag er vigtig i denne proces, mener sociologen Colin Campbell. Det vil sige, at vi mærker efter, om vi kan lide lige præcis den smag, følelse eller oplevelse, det giver os (Campbell, 2004). Dette gælder også religiøsitet, hvor informanternes helt personlige præferencer ofte bliver nævnt $\mathrm{i}$ begrundelsen for deres fravalg af nogle former for religiøsitet, som eksemplet med folkeskolelæreren Henrik viser her, hvor jeg har stillet spørgsmål om, hvorvidt Henrik har været inde i hospitalskirken:

Nej, det har jeg ikke. Jeg føler lidt det, når jeg kigger ind i kirken, jeg har selvfølgelig kigget ind i den, når jeg skulle ned og have taget blodprøver, jeg har følt, der er lidt ensomt derinde. Jeg siger jo også det der med, at grunden til, at jeg måske har fået et lidt abstrakt forhold til kirken, det er også, fordi jeg forbinder det måske, det jeg forbinder det mest med det er måske sorgen altså, det tror jeg, altså døden frem for ... Og så synes jeg, det virker sådan lidt koldt altså. Det er ikke sådan tiltalende for mig at skulle gå derind og sidde og bede en bøn eller sidde og tænke nogle tanker. (Interview med Henrik d. 9. juni 2009)

At folkekirken forbindes med død og sorg, giver andre informanter også udtryk for. Den religiøse vare, som i dette tilfælde kirken, er lavt værdisat, fordi den forbindes med noget negativt, sorg og død. Kirken er "kold" og "ikke tiltalende", mener Henrik, og derfor ikke en vare, som han vil forbruge og vælge til. Religiøsiteten vælges, forbruges og forhandles af informanterne, som Henrik, ud fra deres 
behov i skabelsen af deres autentiske selv. Og at have dette autentiske og selvvalgte selv er med til at højne deres værdi i det (post)moderne forbrugersamfund.

Det er endvidere bemærkelsesværdigt, at selvom Henrik har en dødelig sygdom, så må den religiøse forbrugsvare ikke forbindes med døden. Den religiøse vare skal i stedet give andre oplevelser. Religionen forventes her - ligesom andre varer - at kunne give positive oplevelser, eksempelvis tid og ro i sjælen. I analysen af informanternes religiøsitet fandt jeg, at de ikke i nævneværdig grad troede på et liv efter døden. For forbrugersamfundets individer er efterlivsforestillinger ikke en særligt attraktiv vare, hvorimod de religiøse varer, der kan give øjeblikkelig tilfredsstillelse, efterspørges i højere grad. Ligesom varer, der kan konsumeres hvor som helst og (næsten) når som helst, er mere attraktive, såsom bøn eller meditation. Denne fornemmelse for øjeblikkelig tilfredsstillelse, også i forbindelse med religiøsiteten, implicerer noget særligt for forestillingen om tid og religiøsitet, da religiøsiteten hermed bliver noget, der kan vælges til - for øjeblikkelig tilfredsstillelse. Og vælges fra hvis religiøsiteten ikke giver denne tilfredsstillelse. I forhold til opfattelsen af tid betyder det også, at kontinuitet og brud følges, og dette vil jeg nu vende blikket mod.

\section{Religiøsitet efter behov}

I min forskning har jeg arbejdet med et religiøsitets begreb, jeg har kaldt p.n. religiøsitet, det vil sige Pro necessitate religiøsitet. Dette skal forstås som religiøsitet, som sidestilles med andre muligheder, og som man kan forbruge efter behov ${ }^{6}$. En af de informanter, der beskrev denne måde at forholde sig til religiøsitet på, var Henrik, som her bruges som illustration på denne måde at forstå religiøsitet på.

Henrik beskriver sig selv som overbevist ateist, og da jeg spurgte, om Henrik havde taget sin ateisme op til overvejelse i forbindelse med, han blev syg, svarede han:

Mja selvfølgelig har jeg haft det til overvejelse, om det kunne hjælpe en, men stadig i min situation, jeg kan ikke vide, hvis jeg kommer ud i en mere ekstrem situation, hvor jeg fik at vide, at der var 15 pct. chance for at blive helbredt, så kunne det godt være, jeg ville tage det op til overvejelse. Men tanken om at jeg fra starten af har fået at vide, at der var 100 procents., næsten 100 procents garanti for, at jeg blev helt rask, det har jo gjort, at jeg ligesom har bibeholdt den måde, jeg stadig tænker på altså som før. (Interview med Henrik d. 9. juni 2009) 
Da jeg stillede Henrik spørgsmålet, tænkte jeg mest på, om han var blevet religiøs i forbindelse med sygdommen, men Henrik svarede anderledes, end jeg forventede. I citatet ovenfor giver Henrik udtryk for forbrugervalget i den videste forstand. Henrik ved - idet han er overbevist ateist - at der ikke findes en Gud, alligevel så anser han religiøsiteten, som noget han kan vælge til og fra, for eksempel hvis han skulle blive mere syg. Henrik mener, at skulle han få brug for det, så kan han altid vælge at blive religiøs. Men nu hvor han ikke har brug for det - hans prognoser er gode - så er han det ikke. En religiøs guddommelighed eksisterer ikke, men samtidigt kan det vælges til, og dermed har det alligevel en eller anden form virkelighed.

Ovenstående citat viser hermed, at religiøsiteten ikke kun er et statisk individuelt religiøst reservoir, som i høj grad er kontinuerligt med tidligere religiøsitet, og som kræver et brud i form af en oplevelse af, at det man tror på, ikke er adækvat til at håndtere den krise, man står i. Jeg mener, at citatet derimod beskriver, hvordan Henrik ikke er religiøs - han har ikke noget religiøst reservoir, men at han ved, at religiøsitet findes, og han ser det som sin ret at forbruge og tilvælge religiøsitet, hvis han skulle få behov for det. Med alt andet i sit liv, og som i samfundet generelt, er Henrik blevet vant til at kunne vælge. Som sociologen David Lyon påpeger om denne rettighed:

"Consumer choice has, in turn become the criterion for much more than shopping. Such skills are now required in education, health and off course politics, where the slogan "free to choose" has achieved credal status." (Lyon, 2000, p. 12)

Henrik giver udtryk for, at selv i den situation at hans prognoser var dårligere, og han ville vælge religionen til, så ville hans valg være et klart forbrugervalg, hvor han ville vurdere, hvad der passede bedst til hans behov:

Jamen som jeg sagde i starten, jeg tror, jeg skal mere ud i ekstremerne, før jeg skal kunne ændre et eller andet, hvor jeg, fordi det tror jeg godt, jeg kunne have behov for, men jeg siger jo bare, det er ikke ensbetydende med, at jeg skulle være kristen, men det kunne være noget buddhisme, hinduisme eller et eller andet, som kunne være interessant at dyrke, fordi man netop er så langt. (Interview med Henrik d. 9. juni 2009)

Dermed er religiøsiteten blandt informanterne ikke et bestemt reservoir betinget af tidligere religiøsitet, men derimod gør forbrugervalget det til et uendeligt reservoir af muligheder, hvori brud og kontinuitet er simultane muligheder. Henrik giver udtryk for, at han kunne vælge hvad som helst, alt efter hvad der ville 
være interessant at forbruge. Dermed bliver det et valg, der ikke kun foretages ud fra den kristne religiøsitet, som Henrik er opvokset i, og som han har med sig. Men han kan samtidigt bevare kontinuiteten i forhold til sin ateisme generelt. Når Bauman i hans diskussion af forbrugersamfundet påpeger, at forbrugerismen er en "principal propelling and operating force of society" (Bauman, 2007, p. 28), så gælder det også for disse danske patienter, der udtrykker, at de har fuldstændig valgfrihed af religiøsitet i hvert et øjeblik. Det er denne tendens, sociologen Grace Davie udtrykker som en bevægelse fra "obligation to consumption" og uddyber det distinkte og øjeblikkelige således:

I go to church (or to another religious organization) because I want to, maybe for a short period or maybe for longer, to fulfill a particular rather than a general need in my life and where I will continue my attachment so long as it provides what I want, but I have no obligation either to attend in the first place or to continue if I don't want to. (Davie, 2005, p. 291)

Jeg mener, at denne forbrugermåde at forholde sig til religiøsitet efter behov og lyst kan kaldes pro necessitate religøsitet, hvor religiøsitet kan "tages" som medicin for at lindre et øjeblikkeligt behov. Samtidigt hermed - at religiøsiteten bliver set som en mulighed - giver informanterne udtryk for, at det er fjernt for dem at konvertere eller ændre religiøsitet fuldstændigt. Men det behøves heller ikke at ændre sig fuldstændigt, når man kan "tage" religiøsiteten p.n., som Søren påpeger i det følgende citat, som handler om tro på et liv efter døden:

Jeg tror, den dag hvor man står med kniven for struben, der vil man måske tro, at selvfølgelig er der det [et liv efter døden]. Jeg tror, i de situationer, man bliver presset der har man mere behov for at tro på noget, end man har, når det går godt. (Interview med Søren d. 15. januar 2010)

Idet religion er en mulighed, så knyttes den til, hvor dårligt informanterne har det, og de ved, at hvis de får det dårligere, eller deres prognose bliver ringere, så har de mulighed for at tilvælge religiøsitet efter behov.

Som jeg beskrev indledningsvist, så betød forbrugersamfundet en tidslig opfattelse, hvor øjeblikket er det eneste, der (virkelig) tæller. Som Bauman påpeger, er livets muligheder kun tilstede i øjeblikket grundet hastigheden i forbrug og smid væk kulturen. Når øjeblikket er væk, er muligheden også forpasset, og vi har bevæget os videre til den næste mulighed (Bauman, 2007, pp. 32-33). Med denne tidsopfattelse følger der, ifølge Bauman, et opgør med kontinuiteten: 
Pointillist time is more prominent for its unconsistency and lack of cohesion than for its elements of continuity and consistency; in this kind of time whatever continuity or causal logic may connect successive spots tends to be surmised and/or construed at the far end of the retrospective search of intelligibility and order, being as a rule conspicuously absent among the motives prompting the actors' movement between points. (Bauman, 2007, p. 32)

En anden måde denne øjeblikkelige tidsopfattelse slår igennem på, er i informanternes opfattelse af deres religiøsitet som værende både kontinuerlig og øjeblikkelig. Jeg citerer her Henrik igen, da han udtrykker det bedst, angående en anden gang han forbrugte religion efter behov, nemlig ved en HF eksamen:

Henrik: Jeg har mere den der med, jamen jeg kan også sige i relation til f.eks. sidste gang, jeg egentlig kan huske, jeg brugte Gud, det var inden en eksamen, hvor jeg var desperat, jeg vidste, jeg ville dumpe, jeg havde det ikke godt med det på HF, det har været i 1994, der brugte jeg det, det kan jeg huske, hvor jeg sidst har brugt det sådan i reel betydning.

Nadja: Havde det en betydning for dig der, eller var det bare sådan for alle tilfældes skyld?

Henrik: Jamen det havde en betydning, fordi jeg kom ind og fik en god karakter, jeg trak det eneste emne, jeg overhovedet kunne, det var sådan helt, jeg var virkelig, virkelig, jeg havde det virkelig skidt, jeg var ikke rigtig forberedt og havde ikke kunnet forstå stoffet ordentligt.

Så jeg ved ikke /

Nadja: Du fik ikke sådan en fornemmelse, at det var af den årsag, dine bønner blev hørt, og det kunne du benytte dig af en anden gang, eller var det bare sådan, nå men det var heldigt?

Henrik: Det har nok været. Idag tror jeg mere på, det var held. Men jeg synes ikke, jeg har haft noget behov for, som jeg siger til dig, jeg har ikke oplevet noget, hvor altså jeg tror, der skal noget virkelig tragisk til, før jeg måske skal blive mere religiøs igen. Jeg ved ikke, hvad jeg skal tro. Men når jeg er mere overbevist om, at der ikke er nogen højere magter, altså det er tanken om, hvorfor vil der så ske sådan nogle ting i verden, hvorfor skal de der, der er lige død 228 mennesker i et fly, hvad 
er årsagen til det, det giver ikke nogen mening for mig, de har da ikke fortjent at dø.

(Interview med Henrik d. 9. juni 2009)

Som skrevet tidligere, er Henrik fuldstændig overbevist ateist og pointerer dette gentagne gange, han har absolut ingen religiøs praksis og overvejer kraftigt at melde sig ud af folkekirken. Han ved, han ikke skal giftes i kirken, og hans fremtidige børn skal ikke døbes i kirken, og han har heller ikke brugt alternativ behandling. Men alligevel giver han udtryk for, at religiøsitet er som en overfrakke, han kan tage på og af, og at dette er helt øjeblikkeligt fæstnet. Det øjeblik omkring HF eksamen betyder ikke noget for resten af hans liv, medlemskab af kirken, religiøsitet eller praksis ellers. Men lige i det øjeblik i 1980'erne, dér troede han. Ligesom han troede i øjeblikket bagefter, hvor bønnen virkede. Bagefter var han ikke-religiøs igen og er det også i forbindelse med sin sygdom, hvor han ikke har bedt en eneste gang. Dermed opretholder Henrik kontinuiteten samtidig med muligheden for forbrugerens frie religiøse valg. Henriks bøn omkring eksamenen ændrede ikke hans grundlæggende oplevelse af, hvem han er, ej heller ændrede det hans religiøsitet efterfølgende. Og dette endda selvom bønnen umiddelbart hjalp - han kom op i det, han havde bedt om.

Jeg påpeger hermed, at den kontinuerlige tidsforståelse ikke er dækkende i forhold til at kunne beskrive religiøsitet bredt i forbindelse med sygdom specifikt, og nok også religiøse forandringer generelt. Derimod mener jeg, at man skal omtænke værdi- og religiøsitetsbegrebet, så det både kan indeholde kontinuitet og brud - samtidigt (figur 2).

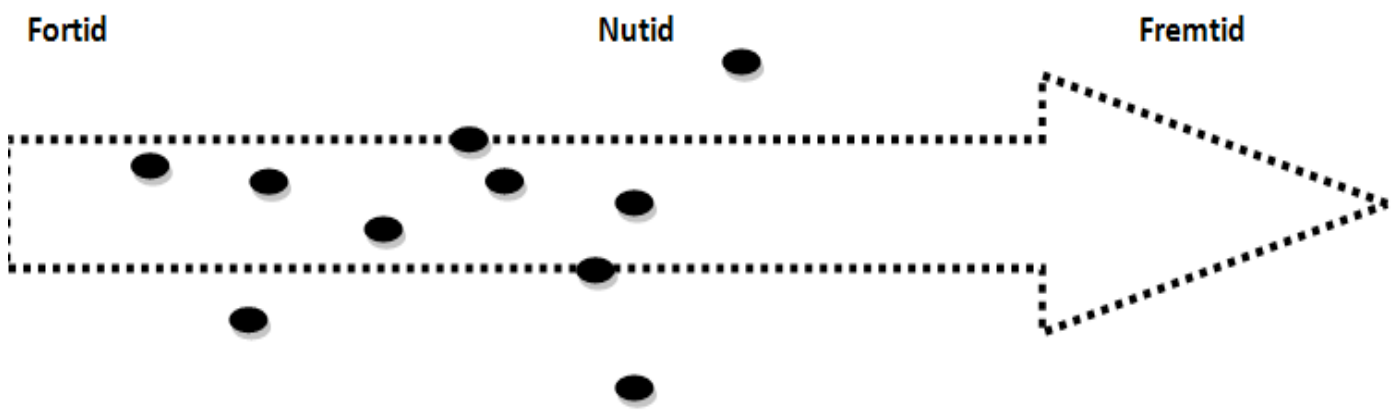

Figur 2 Værdier - kontinuert (pil) og øjeblikkeligt (dots) 
I figur 2 har jeg søgt at vise, hvordan et menneskes værdier kan forandres over tid, i mindre øjeblikke uden at kontinuiteten brydes. Religiøsiteten kan ændres i øjeblikket (de sorte pletter), hvor man kan afstikke fra kontinuiteten (den stiplede pil). Det handler ikke for Henrik om i de ovenstående citater, at han grundlæggende bliver en anden med nye værdier, men at der i stedet er stor mulighed for, inden for kontinuitetens rammer at forbruge efter behov, også selvom dette skulle betyde, at man for en stund skal tro på noget andet, end man ellers gør. At forbruge religiøsitet efter behov, er således en mulighed, hvori der findes en stor grad af kontinuitet. Den religiøse forandring kan dermed være øjeblikkelig og fuldstændig situationel, uden at informanterne bryder med fortiden.

Således er der i denne forståelse af krise og værdier ikke en direkte forbindelse mellem krisens alvorlighed, værdi og værdiskift. Men i stedet kan forskellige begivenheder føre til et øjeblikkeligt behov for at skifte værdier, samtidigt med at man kan holde fast i sig selv, og hvem man var før. Dermed er der også et behov for at samtænke teorierne om forbrugerkulturens tidsopfattelse og traditionel opfattelse af kontinuer tid, når man studerer værdiskift og religiøsitet i forbindelse med livskriser.

\section{Sammenfatning}

I denne artikel har jeg vist, hvorledes tidsbegrebet i forskningen i religiøs coping ikke er tilstrækkeligt til at beskrive, hvordan informanterne forstår og beskriver tidsligt brud og kontinuitet. Dette betyder endvidere, at man ikke kan sætte lighedstegn mellem krise og et blivende brud med, hvem man var før krisen. Tværtimod forbliver informanterne meget tro overfor, hvem de var før sygdommen, men forbeholder sig retten til at forbruge religiøsitet, som de vælger at forbruge andre varer. Dermed får informanterne mulighed for at skifte værdier - og brud og kontinuitet bliver simultant og øjeblikkeligt. I stedet har jeg argumenteret for, at informanterne sammen med deres forestillinger om kontinuerlighed i forhold til hvem de var før sygdommen, fastholder retten til at skifte religiøsitet i øjeblikke. Denne anden forståelse af, hvorledes forandring hænger sammen med, hvem man var før krisen, har betydning for den måde, vi i fremtiden må studere religiøsitet eller andre værdier i forbindelse med fx sygdom, hvor undersøgelsestidspunktet derfor kan få stor betydning for de svar, forskeren får. Endvidere har de implikationer for det sundhedsprofessionelle arbejde, da der kan være forskelle på religiøsiteten i går, i dag og i morgen hos patienten. Eller sagt på en anden måde, religiøsiteten 
betyder måske særligt meget i brydningspunkter i menneskets liv, uden det betyder, at religion altid er til stede hos individer som isbjerget under vandet på andre tidspunkter.

\section{Noter}

1. Artiklen er primært baseret på en analyse fra mit ph.d. studium (Ausker 2012)

2. Værdier er I Pargaments optik ofte ækvivaleret med religiøsitet, eller i det mindste med det som individet finder "helligt"

3 Pargament fortsætter argumentet om det religiøse reservoir med at skrive: "in the shift from abstract to concrete, from potential to actual, the nature of religion come in to sharper focus....These times [difficult times] provide one of the clearest windows into religious experience" PARGAMENT, K. I. 1997. The psychology of religion and coping, theory, research, practice. New York, Guilford Press, p. 5.

4 Inklusionen foregik ved at jeg henvendte mig til alle nydiagnosticerede cancerpatienter på hæmatologisk Klinik på Rigshospitalet. Patienterne skulle være født 1. januar 1970 eller senere, og inklusionsperioden som strakte sig fra 1. oktober 2008 til 31. januar 2010. 3 patienter blev ekskluderet pga. alder (under 18 år) eller tidligere kræftsygdom, 6 takkede nej til at deltage og 21 sagde ja.

5 En mere uddybende beskrivelse af informanterne i undersøgelsen findes i ph.d.-afhandlingen "Tid til forandring" (Ausker 2012)

6 Begrebet er udsprunget af begrebet p.n. medicin, som er lægeordineret medicin der af gives efter behov, det er eksempelvis smerte- eller kvalmestillende præparater.

\section{Referencer:}

Ahlin, L. (2005). Pilgrim, turist eller flykting?, en studie av individuell religös rörlighet i senmoderniteten, Lars Ahlin. Stockholm: Stockholm : Symposium.

Ammerman, N.T. (2007). Everyday religion : observing modern religious lives. Oxford ; New York: Oxford University Press.

Andersen, P.B., Ausker, N., \& Cour, P.l. (2011). Går fanden i koster, når han bliver gammel? In P. Gundelach (Ed.), Store og små forandringer. Danskernes værdier siden 1981. København: Hans Reitzel.

Ausker, N. (2004). Den spirituelle søger. Speciale.: Københavns Universitet.

Ausker, N. (2012). Tid til forandring? Forhandlinger af religiøs kontinuitet, forandring og forbrug hos kræftpatienter i Danmark. Det Humanistiske Fakultet: Københavns Universitet.

Bauman, Z. (2007). Consuming life. Cambridge ; Malden, MA: Polity Press.

Campbell, C. (2004). Metaphysical Basis of Modern Consumerism. In H. Brembeck, \& K. Ekström (Eds.), Elusive consumption. Oxford: Berg Publishers. 
Cour, P.1. (2008). Existential and religious issues when admitted to hospital in a secular society: Patterns of change. Mental Health, Religion \& Culture, 11, 769-782.

Davie, G. (2005). From Obligation to Consumption: A Framework for Reflection in Northern Europe. Political Theology, 6, 281-301.

De Vaus, D.A. (2005). Research design. London: SAGE.

Heelas, P. (1996). The New Age movement : the celebration of the self and the sacralization of modernity. Oxford ; Cambridge, Mass., USA: Blackwell.

Heelas, P. (2008). Spiritualities of life : new age Romanticism and consumptive capitalism. Malden, MA: Blackwell Pub.

Johannessen-Henry, C.T., Deltour, I., Gregersen, N.H., \& Johansen, C. (2010). Religious belief and coping with cancer - a quantitative study among Danish cancer survivors. Research in Faith and Health in Secular Society 17-19 May 2010. SDU.

Koenig, H.G. (2009). Research on religion, spirituality, and mental health: a review. Can J Psychiatry, 54, 283-291.

Koenig, H.G., King, D.E., \& Carson, V.B. (2012). Handbook of religion and health. Oxford ; New York: Oxford University Press.

Layder, D. (1998). Sociological practice: linking theory and social research. London: SAGE.

Luckmann, T. (1967). The invisible religion; the problem of religion in modern society. New York,: Macmillan.

Lyon, D. (2000). Jesus in Disneyland : religion in postmodern times. Cambridge, UK ; Malden, MA: Polity Press in association with Blackwell Publishers.

Mikaelsson, L. (2006). Studiet av livsskildringer i religionvitenskapen. In S.E. Kraft, \& R.J. Natvig (Eds.), Metode i Religionsvitenskap. Oslo: Pax Forlag A/S.

Monat, A., \& Lazarus, R.S. (1985). Stress and coping : an anthology. New York: Columbia University Press.

Pargament, K.I. (1997). The psychology of religion and coping, theory, research, practice. New York: New York : Guilford Press.

Pargament, K.I., Magyar-Russell, G.M., \& Murray-Swank, N.A. (2005). The sacred and the search for significance: Religion as a unique process. Journal of Social Issues, 61, 665-687.

Pargament, K.I., \& Raiya, H.A. (2007). A decade of research on psychology of religion and coping: things we assumed and lessons we learned. Psyke $\mathcal{E}$ logos, 28, 742-766.

Rambo, L.R. (1993). Understanding religious conversion. New Haven: Yale University Press.

Repstad, P. (2007). Mellom nærhet og distanse. Kvalitative metoder i samfunnsfag. Oslo: Universitetsforlaget.

Robbins, T. (1988). Cults, Converts, and Charisma: the Sociology of New Religious Movements: Sage Publications.

Roof, W.C. (1999). Spiritual marketplace : baby boomers and the remaking of American religion. Princeton, N.J . Princeton University Press.

Smith, T. (2006). The National Spiritual Transformation Study. Journal for the Scientific Study of Religion, 45.

Thune-Boyle, I.C., Stygall, J., Keshtgar, M.R., Davidson, T.I., \& Newman, S.P. (2012). Religious/spiritual coping resources and their relationship with adjustment in patients newly diagnosed with breast cancer in the UK. Psychooncology.

Warburg, M. (2008). Theorising Conversion. In E. Barker (Ed.), The Centrality of Religion in Social LIfe. Essays in honor of James A. Beckford. Hampshire: Ashgate. 
Wuthnow, R. (2005). America and the challenges of religious diversity. Princeton, N.J.: Princeton University Press. 